\title{
The diffusion of pay for performance in health system reforms in sub-Saharan Africa and the depoliticization of health intervention
}

\author{
Pierre Abomo \\ Postdoctoral Research Assistant, Liverpool School of \\ Tropical Medicine, Liverpool, United Kingdom \\ pierre.abomo@Istmed.ac.uk
}

Abstract Since its commencement in Rwanda in 2006, the study of performance-based financing (PBF) in Africa has focused research attention on its effects regarding improving the health care system or achieving health-related Millennium Development Goals (MDGs). Similarly, critics of PBF have concentrated more on its inability to transform structural indicators of the health system positively and sustainably. So far, the scientific literature has not sufficiently explored the implications concerning the ideological and operational mutations that the PBF is operating. This study investigates these aspects of PBF in conception and operationalization of public health intervention. The concept of depoliticization of public health action is proposed in this analysis to describe the capacity of the PBF to redraw health policy from the realm of political and State intervention, and from the primacy of public sector to field of market-based competition between Government sponsored and non-State actors.

Keywords: Performance-based financing, Africa, depoliticization, policy diffusion.

\section{Introduction}

For a decade, Pay for Performance (P4P) has asserted itself as the new instrument for health system reform in sub-Saharan Africa (SSA) (Soeters; Vroeg, 2011). Widely known as Performance-Based Financing (PBF), international donors promoted this reform (Boyoko, 2017), as well as epistemic communities advocating for the acceleration of the achievement of health-related 
Millennium Development Goals (MDGs) by 2015. Since 2006, PBF in SSA has gained significant momentum in SSA following initial experiences through pilot projects, and then national scale-up in Rwanda (Basinga et al., 2011; Rusa et al., 2009; Soeters; Habineza;Peerenboom, 2006) and Burundi (Bonfrer;Van de Poel; Van Doorslaer, 2014; Nimpagaritse et al., 2016; Rudasingwa; Soeters;Bossuyt, 2014; Rudasingwa;Uwizeye, 2017). Proponents of PBF presented its expansion in more than thirty additional countries as proofof its effectiveness (Soeters;Vroeg, 2011). Likewise, many authors have pointed to improvements in the attainment of health-related MDGs, particularly in Rwanda and Burundi (Basinga et al., 2011; Rudasingwa; Soeters; Basenya, 2017), two pioneer countries in the introduction of PBF in Africa. However, discordant voices are increasingly being heard. A growing body of empirical studies demonstrate the limits of this reform such as cherry-picking, The bribing of the control agents responsible for carrying out the assessments.false reporting, and cheating (Oxman; Fretheim, 2009; Paul et al., 2018; Paul; Sossouhounto; Eclou, 2014; Turcotte-Tremblay et al., 2017). While false reporting refers to the fact that unverifiable information and declared in order to secure positive assessments, cheating relates to the manipulation of data.Critics are challenging the effectiveness of $\mathrm{P} 4 \mathrm{P}$, which was used by international donors to justify its dissemination across SSA. Among the most severe critics are those stressing the weakening of the health system by PBF in Africa (Paul et al., 2017)in the sense that the opportunity to develop an independent and self-sustain health system is missed out;or the development of perverse effects among health professionals (Ireland; Paul; Dujardin, 2011; Shen et al., 2017).

It is striking that the effects of PBF are only considered from a strictly technical and operational point of view. There is limited research yet that investigates the political and ideological implications of introducing $\mathrm{P} 4 \mathrm{P}$ in the context of institutional fragility and state-building in SSA. Indeed, beyond the positive or negative effects of PBF, it can already be observed that its design and implementation process ipso facto lead to a depoliticization of health policy. The concept of depoliticization, which is central in this paper, is drawn from "anti-politics" (Darbon, 2009; Fawcett et al., 2017; Schedler, 1996) and post-politics theories (Laine, 2009; Mouffe, 2013). It aims at describing two empirical realities. Firstly, it depicts the changes in the design of health policy wherein both the political object and subject are expelled or neutralized from public policy engineering. Secondly, it describes the process of outsourcing of implementation mechanisms of public policy and their transfer to non-state actors. The purpose of this paper is to illustrate to what extent the design and implementation of PBF in SSA contribute to the general trend of depoliticization of public policy, including health policies.

This discussion paper draws from data collected during interviews with PBF experts and health professionals. I explain how depoliticization occurred during the design and the implementation of PBF programmes in Africa. 


\section{The marginalization of national stakeholders and policymakers in the design of Performance-Based Financing schemes in Africa}

The marginalization of national stakeholders and policymakers in the design of PBF refers to the fact that, critical national authorities in charge of designing and implementing public policies were side-lined during the conceptual phase of PBF. Indeed, being a project promoted and financed by international actors, the involvement of local policymakers in PBF concerning the definition of its goals, scope, and indicators, was insufficient. International actors in association with a few local interlocutors who had been identified and trained as "local champions," did all the technical design and conceptualization of PBF.

Hence, the first task of international advocates of PBF was to identify and train PBF local champions selected mostly among agents intervening at the intermediary and peripheral levels of responsibilities. The purpose of the training was to allow them to take ownership of the instrument and become local champions for its promotion. The training focused on convincing participants of the failures and ineffectiveness of traditional approaches to public policy featuring the State and public-led entities in managing the health facilities. Innovations introduced by PBF were presented, as well as their theoretical justifications: the economic theories of the agency, market-based advantages compared to State intervention, the theory of public choice and New Public Management (SinaHealth, 2018). For example, in Burundi,AEDES organized, in partnership with the World Bank, the European Commission, and Cordaid, a Regional Seminar on the purchase of health services under PBF in Bujumbura in 2010. The objective of this seminar was:

to bring together some 100 actors from the region who are active in performance/ outcome-based funding systems, and to discuss technical issues facing these actors. Beyond the principles and the theory, this seminar aimed to highlight the successes and the limits of the financing systems put in place. (Aedes, 2010, p. 1)

This seminar brought together professionals active in the purchasing function (of services or performance) and the regulatory role of the health system (Aedes, 2010).

The objective of this recruitment strategy of the participants is not only to convert to the new doctrine the people needed for its dissemination but also to have "PBF champions within the Ministry of Health capable of informing decision-makers". (Statement by a Member of the CoP PBF community of practice, (2017, July). Similarly, the training strategy aims to endogenize PBF by making it appear to the public not as a donorpromoted instrument, but as a genuine demand from local communities:

If we want PBF programs to be sustainable, we need to ensure that this great idea can appear as coming from the local population (down-top approach) and that more emphasis is put on a gradual, systematic change rather than on the financial benefits. Statement by a Member of the CoPPBF community (2017, August). 
Typically, in addition to the theoretical knowledge acquired, the participants also shared their national experiences and learned from each other. By so doing, an epistemic community emerged with the mission of building convergences in the implementation of PBF. Besides, at the end of training sessions, specific recommendations and action plans for the next steps for the diffusion of PBF were drafted for every country represented. In the case of Cameroon, the recommendations made during the training session held in August-September 2017 invited participants to undertake the following strategies targeting senior decision-makers within the health system:

- At the level of the Ministry of Health: Advocating at the Ministry to ensure the decentralization of personnel management and the payment of the providers' subsidies in a timely fashion;

- At the level of religious leaders: Ensuring the autonomy of faith-based health providers;

- At the level of the providers: Applying the index tool with the principle of putting all the revenues in a common basket;

- At the level of Contract Development and Verification Agency: Establishing investment units for the improvement of infrastructure and equipment of health facilities. (Sina Health, 2017).

The training process is designed to address the consequences of the top-down approach that guided the introduction and implementation of PBF scheme.Indeed, the topdown approach that guided the introduction of the reform created some resistance among decision-makers particularly within Senior policymakers from the Ministry of Health and Finances. The purpose of this lobbying strategy is to reintegrate decision-makers who were sidelinedduring the design and introduction of the tool.For instance, during one of the training sessions held in Ngaoundéré, Cameroon, the following recommendations were made to participants as hierarchical injunctions to lobby their Government:

- Implementing PBF in all regions of Cameroon;

- Establishing a legal and institutional framework to protect health facility managers under PBF;

- Distributing the PBF manual accompanied by a letter from the Ministry, explaining best practices, free competition between the actors... the financial autonomy of health facilities;

- Resolving with the Minister of Finance the problem of the autonomy of management of health facilities and pay operating funds to health facilities in cash (and not in the form of vouchers);

- Decentralizing human resources management at the regional level: allowing health facility managers to recruit staff;

- Stimulating competition by promoting market access to other drug distributors. (Aoudi et al., 2017). 
These recommendations point to a blockage facing the scheme in Cameroon where both national scale up and institutional ownership are in jeopardy because important public policy and decision makers have been ousted throughout the process. The effort to get them involved afterward has proven to be difficult as they see the PBF scheme as a threat to their policy influence and power. This difficulty could have been prevented by a better mapping of all stakeholders and key players in the policymaking process of recipient countries, and their inclusion right from the beginning of the processes, e.i. from the design phase. The idea of using a pay for performance scheme to accelerate results in the health system could have been discussed, negociated and approved by both international and national partners before its operationalization. Therefore, the gamble of getting rid of politics and politicians to be effective seems to have failed. The desire to rally them to the cause later seems much more challenging than their inclusion at the initial stage of the process (Shroff et al., 2017).

\section{In the implementation of PBF}

In the implementation process of PBF, international actors still have the upper hand. Firstly, they play an essential role in the steering committee of PBF which has the responsibility of making strategic decisions such as defining performance indicators and financial thresholds for their payment. In the example of Cameroon for instance, the Steering committee, which is made up of national stakeholders (Ministries of health, Finances and arms forces) and international development organizations (The World Bank, UNICEF, WHO, UNICEF, UNFPA, GAVI, Cordaid, European Union, $\mathrm{AFD}, \mathrm{KfW}$ ), one of the most influential members has the right to approve or reject changes in the definition or choice of paid indicators. According to the PBF procedures manual, "Any changes to the procedures manual must be submitted to the World Bank for no objection" (Consortium AEDES/IRESCO, 2012). "Besides, also oversees the project's impact assessment work with all its technical expertise" (Consortium AEDES/IRESCO, 2012).Secondly, international actors led the piloting phase of PBF that was critical in the decision to scale up the programme. Even though this is not specific to PBF, this critical step towards the national adoption of PBF as it is designed to shape the advocacy discourse and strategy in favor of the instrument.Thirdly, since the piloting phase was completed, they have been having a decisive role in the operational activities of PBF:

- Supporting the external auditing and verification process: In the institutional chain of PBF implementation, international actors such as NGOs act as outer and "independent" actors to verify the quantities of services declared by health facilities;

- Supporting in the evaluation of the performance of PBF: the assessment of PBF in Cameroon so far have been carried out by international players such as the NGOs Cordaid, IRESCO or they have been ordered by the World Bank. The World Bank a significant number of impact evaluation of PBF schemes in Rwanda, 
Burundi, Cameroon or Benin. For example, in 2011 the World Bank sponsored, in partnership with the Government of Netherlands, The British Economic and Social Resear Council andthe Government of Rwanda, the impact evaluation of PBF on maternal and child health services in Rwanda (Basinga et al., 2011). Similarly, in 2017 the World Bank sponsored the impact evaluation of PBF (de Walque et al., 2017).

In total, the implementation process of PBF scheme leaves very little roomfor maneuver for national policymakers. This limited involvement of national decision makers is reinforced by capacity and financial gaps faced by most SSA countries.

\section{II- The outsourcing of the implementation process of pay for performance schemes and the replacement of public actors by non-state actors}

The outsourcing of a public policy process accounts for the fact that public sector core activities and responsibilities are transferred to non-state and private sector agents. This process is also known as the "publicization of private sector intervention" (Bergeron; Castel; Nouguez, 2011), which implies the infusion of private sector techniques throughout the public sector. The private sector in the context of this paper refers to for-profit organizations whose activity follows the logic of performance and productivity specific to the market economy.

The increasing role of management consulting firms in the engineering of health policy under pay for performance

Management consulting firms are among the private sector actors that have benefited the most from privatization of public health policy delivery. As this has become a complicated process of technical engineering, management consulting firms have emerged as key players for public managers. This mutation in the realm of public and health policy is triggered and strengthened by P4P schemes like PBF. Its design and implementation have imposed technical and managerial adjustments such as the development of business plans by health facilities, management dashboards, monitoring and evaluation frameworks, data collection and statistical analysis, which require skills that lack in many low and middle-income countries like Benin, Burundi or Cameroon. Also, the underlined requirements attached to PBF about effectiveness and efficiency urge health facilities to contract out many of their activities to management consulting firms.

In $\mathrm{P} 4 \mathrm{P}$ schemes in Africa, management consulting firms have played a leading role as intermediary actors between international donors (who they trust the most compared to national decision-makers, who are deemed corrupt) and national actors (Ministries, community organizations and health facilities). For instance, in Cameroon, the IRESCOAEDES consortiumhas been the principal architect of PBFengineering. The consortium is made up of AEDES, a Belgian Consulting firm specialized in public health with recipient 
of many outsourcing contracts in the implementation of PBF; and IRESCO, private research institute based in Cameroon and focusing on Socio-economic development and communication. This consortium was recruited, thanks to funding from international donors, to set up the various PBF pilot projects in the country. The involvement of the IRESCO-AEDES consortium provides a comprehensive overview of the vital role now played by these private actors in the deployment of PBF. This configuration is similar to contexts in Benin, Rwanda, and Burundi with a few exceptions (for instance, IRESCO is only active in Cameroon).

The outsourcing of public policy operations is another clear example of the ongoing depoliticization of public health and policy action. Private sector actors do not have the same constraints and incentives as public facilities. The question of political responsibility, which goes hand in hand with public decision-making in sectors as sensitive as health policies, does not similarly structure the behavior of public actors whose public responsibility is clearly identifiable. For profit business entities by their modus operandi are forced to make decisions that promote their profits, while public actors are constrained to favor actions ensuring the general interest even when their economic profitability can be difficult to measure. In the health field for instance, it is the case with health promotion and prevention policieswhere the profitability and measurability may be difficult to showcase even when they prove useful for the general interest. This is also the case in health insurance where the constraint of financial profitability of a private insurer can push it decline the benefits of health insurance to poor citizens. Thus, health policy decisions remain eminently political choices that should not escape the traditional process of policymaking whose decisionmakers are accountable to their fellow citizens. Therefore, the growing influence of forprofit private sector entities like consulting firms in the policy process leaves out political and societal necessities which underpin every public policy effort.

\section{The role of community-based organizations}

Like for-profit organizations, community-based organizations engaged in PBF implementation are involved in the depoliticization process of public health action. Despite the difference in role and attributions between the private sector and civil society organizations such as Community-based organizations (CBOs), in the context of PBF implementation, their respective roles produce the same effect.

CBOs are civil society entities made up of rural and local communities. Their members are mentored, trained and sponsored by both international donors and NGOs such as Sina-Health in the context of PBF expansion. In this context, CBOs take in charge many operational aspects of the PBF that could have been devoted to public health facilities at the district, communal, and/or rural levels. PBF institutional mechanisms integrate these actors deemed "neutral" and "apolitical" in the implementation process in order to make it effective. The involvement of CBOs in PBF operations allow them to take charge of some of the critical responsibilities that used to be (or are supposed to be) carried out by public agents. For example, in the implementation of PBF in Burundi, they assume 
significant duties such as: negotiating and signing quarterly performance contracts with the Contracting andVerification Agency, the Health Center in their area and the international NGO in charge of cross-checking health results claimed by health facilities; referring patients to the Health Center and looking for dropouts detected by the Health Center; conducting community-level diagnostic tests and ensuring the home care in cases of malaria, diarrhea and pneumonia in children from 2 to 59 months (Cordaid and IADH, 2014).

In the same vein, $\mathrm{CBO}$ in the PBF scheme take part in decision-making at the level of the health centers under their area of intervention and work closely with the health team to "find solutions for local health problems" (Fritsche, 2014). As far as their activities are concerned, they include identifying, in collaboration with the Health Center team, priority health problems and seeking appropriate solutions; raising awareness and mobilizing the population for health interventions (Vaccination, CPN, family planning, etc.); or participating in the monitoring and evaluation of the implementation of the annual action plans of the health facilities.

Civil society has long been an integral part of the network of public health actors (Lascoumes;Galès, 2005). But their influence in the context of PBF is far more important in the sense that their attributions might imply the creation of a parallel institutional architecture. This movement of empowerment of CBOs sometimes at the expenses of the building and strengthening of already weak policy capacity of the State is particularly visible in the health sector in SSA. This approach of relying more on CBOs than on national bureaucracies is explained by the fact that the civil society movement has retained a positive image and attracts attention as well as funding from international development organizations. They have hailed the intervention of civil society organizations as compensating for the shortcomings of the State (Trefon, 2004). This is the reason why the vision of using civil society organizations as channels for public action has been made a priority, particularly in contexts with weak State structure as it is the case in SSA (Kerouedan;Dauby, 2004), or in developing countries in general (Amanda; Henny, 1998; Haubert, 2000; Marcussen, 1998). In such contexts, the concept of "Global Health" (Alleyne, 2011; Beaglehole; Bonita, 2010) has emerged as an arena where all stakeholders claiming to do good are welcome, especially when they are labeled "civil society" or "community-based organizations". Indeed, these actors are portrayed as acting without a political ideology and beyond the partisan politics which is dismissed in this context of public policymaking. In addition, these civil society actors are praised fortheir contributions to the development of "health democracy" (Akrich;Rabeharisoa, 2012; Domin, 2006; Kerouedan;Dauby, 2004; Letourmy;Naïditch, 2009; Maudet, 2002; Moutel, 2009; Tabuteau, 2013). Their intervention is both encouraged, supported and legitimized by international donors (WHO, 2007). Therefore, developing countries constitutea real testing ground for the ambition displayed mainly by international NGOs to be co-custodians of the management of public affairs, and in some cases, the replacement of public structures in State failure contexts (Marita et al., 2016; Smith; Buse; Gordon, 2016). 
On examining the various missions and activities of these community-based organizations, it appears they embody a project of substituting public health facilities by seizing the tasks traditionally devolved to them. For instance, local health committees' actions go as far as securing health facilities, collecting payments, carrying out diagnoses, administering care, and administrative and financial co-management of health centers.

\section{The consequences of depoliticization through PBF and reception by local stakeholders}

This article raises several questions, including the concept of depoliticization, the consequences that its implementation generate, and the reaction of national political and administrative actors.

First of all, the concept of depoliticization raises the question of its operationalization, and more particularly its measurement in the context of the PBF for example. Indeed, some authors analyze the phenomena of withdrawal of the State or of diminishing its room for maneuver in public action through, for example, privatization processes in Africa, not as a loss of influence of the State. on public action, but a redefinition of its role. For example, Beatrice Hibou considers that "far from becoming powerless in the economic field, the state adapts to external as well as internal constraints. This adaptation is translated into privatization, which is less a loss of control than the option of an indirect government using more and more private intermediaries" (Collectif et al., 1999). Such an analysis would, for example, lead to the rejection of the concept of depoliticization to consider that it would be a redefinition of the role of the state in public health action through the PBF. Similarly, based on Michel Foucault's work on "The Subject and Power" (Foucault, 2001), where power appears as socially diffused and not necessarily in the exclusive hands of a repressive central state. However, the use of the concept of depoliticization in this study implies the understanding of public action as an emanation of political choices whose decision-makers are accountable to their fellow citizens. From this point of view, public action is analyzed as a dependent variable of the politics and its stakeholders. In this paper, I argue that PBF in its design and implementation overshadows the political aspect of which the government and the administrations under its authority are accountable. From this point of view, the indicators to measure the phenomenon of depoliticization through the diffusion of PBF are to be identifiedat two key moments in the cycle of public health action:

At the time of the conception of the public action of health, these indicators are the following:

- The replacement of the political rationale with the economic rationality in the design of PBF;

- The use of scientific metrics to neutralize political debates around possiblealternatives to $\mathrm{PBF}$; 
- The definition of the health system effectiveness according to criteria disregarding socio-political considerations.

At the time of implementation, the indicators to measure the concept of depoliticization are:

- The substitution of public service ethics for the managerial ethos;

- The outsourcing of healthcare provision to operational entities beyond a political accountability or citizen control;

- The framing of the health sector as a competitive market with health facilities competing as for-profit businesses to attract and retain patients turned into customers.

Secondly, the deployment of a depoliticized approach to policymaking leads to a parallel architecture of the health system. In this paper, the depoliticization entailsa set of parallel structuresintervening beyond the control of the national government and empowered to compete with State structures in the provision of public goods. Thirdly, this paper raises the question of the reaction of national stakeholder to what could be consider as undermining their role and position. From a general point of view, it could be particularly difficult for national stakeholders to speak up against international donors and object to their project or approaches given the power disadvantage between the two partners. This could happen occasionally, but it depends on many factors such as the political acumen of the national stakeholder opposing a project proposed by international partners, the level of financial dependence/vulnerability and the policy capacity of national stakeholders that could help them in framing their negotiation position and proposing policy alternatives backed by robust evidence. In the case of Benin, the new Government, politically strengthened by its large victory and lead by a reputable and confident businessman, decided to stop the PBF experiment and proposed another scheme. So, for the "trapped administrator" in countries where socio-political, technical skills and leadership conditions in policymaking are not met the remaining option is to engage in a silent but conscious "policy resistance"(Fox; Staw, 1979) attitudes such as "pace-setting, foot-dragging or fence-sitting" (Börzel, 2002). In Cameroon for instance, policy resistance attitudes are particularly predominant at the Ministry of finances where decision-makers resist to the ideas of taking over the financial commitments to support PBF implementation. Similarly, they refuse to grant the financial autonomy to health facilities required for the PBF scheme to be effective.Consequently, by attempting to bypass politics and the traditional policymaking circuit, PBF promoters put its sustainability in jeopardy. In this context, two parallel health systems emerge, one led by the State and its traditional agents; the other supported by international donors and their implementing agents, which are international NGOs, management consulting firms, and community-based organizations. These two systems that cohabit without mixing, not only contribute to the weakening of the health system, but also to its inefficiency. 


\section{Conclusion}

In this article, I argued that the diffusion of PBF in sub-Saharan Africa and its modus operandi lead to depoliticization of public health action. This depoliticizationis characterizedby the neutralization of politics and its actors in the policymaking process. The indicators and performance measures deemed scientific annihilate the political debate. For-profit business actors and civil society organizations reinforce this depoliticization by replacing and/ or competing with state institutions in the management and provision of healthcare. In reaction, national policy stakeholders using policy resistance tactics to block, delay or render ineffective the deployment of PBF. Therefore, there is a need to rethink the approach of PBF design, introduction and implementation. Beyond the debate about the effectiveness of PBF in SSA is the approach to PBF in SSA, which is the approach to design, introduction and implementation. This initial methodological difficulty makes it difficult to have an honest assessment of its impact.

Following this observation, this paper recommends revisiting the cycle of design and implementation of the PBF to further involve the stakeholders of the recipient countries. This involvement should not simply be limited to formal consultations with the Minister of Health or informal processes with some health professionals chosen by affinity by international actors. The PBF itself proposed by external partners, must be immersed and adapt to the practices of recipient countries in terms of policymaking. The technical expertise required for the design and implementation of the PBF, as well as funding can be provided by international partners with a deliberate ambition to transfer capacity and technical know-how. This also implies that the stakeholders of the beneficiary countries have previously participated in the design of the tool, the definition of its objectives and indicators. Considering such an intervention approach may be late for the PBF in view of its current expansion in SSA, it could however inspire other development cooperation projects between international donors and their southern partners. This shift in the intervention approach would simply means respecting the principles of the Paris Declaration on the effectiveness on aid of 2005.

\section{References}

AEDES. Regional workshop on Performance Based Financing in Bujumbura. Bujumbura, fev. 2010. Disponível em: <http://www.aedes.be/en/news/archives/pbf_burundi.html (>.

AKRICH, Madeleine; RABEHARISOA,Vololona. L'expertise profane dans les associations de patients, un outil de démocratie sanitaire. Santé Publique, v. 24, n. 1, p. 69-74, 12 abr. 2012.

ALLEYNE, George A. O. Global Health: The Twenty-First Century Global Health Priority Agenda. Infectious Disease Clinics of North America, Global Health, Global Health Education, and Infectious Disease: the New Millennium, Part I. v. 25, n. 2, p. 295-297, 1 jun. 2011.

AOUDI, Ibourä̈ma et al. Rapport du 60ème cours PBF Financement Basée sur la Performance. Du 21 Aout au 1er Septembre 2017, $\mathrm{n}^{\circ}$ Version Provisoire 160917. Cotonou: SINA HEALTH, 2017. Disponível em: <www.sinahealth.com/wp-content/uploads/RapCoursPBFCotonouV160917-.pdf>. 
BASINGA, Paulin et al. Effect on Maternal and Child Health Services in Rwanda of Payment to Primary HealthCare Providers for Performance: An Impact Evaluation. The Lancet, v. 377, n. 9775, p. 1421-1428, 23 abr. 2011.

BEAGLEHOLE, Robert; BONITA, Ruth. What is global health? Global Health Action, v. 3, 6 abr. 2010. Disponível em: <https://www.ncbi.nlm.nih.gov/pmc/articles/PMC2852240/> Acesso em: 27 nov. 2018.

BERGERON, Henri; CASTEL, Patrick; NOUGUEZ, Étienne. Un entrepreneur privé de politique publique. Revue française de science politique, v. 61, n. 2, p. 201-229, 6 maio 2011.

BERNARD, Amanda; HELMICH, Henny; LEHNING, Percy B. La société civile et le développement international | READ online. [S.l: s.n.], [s.d.]. Disponível em: $<$ https://read.oecd-ilibrary.org/development/la-societe-civile-etle-developpement-international_9789264263390-fr>. Acesso em: 27 nov. 2018.

BERTONE, Maria Paola et al. Assessing communities of practice in health policy: a conceptual framework as a first step towards empirical research. Health Research Policy and Systems, v. 11, n. 1, p. 39, 20 out. 2013.

BONFRER, Igna;VAN DE POEL, Ellen;VAN DOORSLAER, Eddy. The Effects of Performance Incentives on the Utilization and Quality of Maternal and Child Care in Burundi. Social Science \& Medicine (1982), v. 123, p. 96-104, dez. 2014.

BÖRZEL, Tanja A. Member State Responses to Europeanization.JCMS: Journal of Common Market Studies, v. 40, n. 2, p. 193-214, 1 jun. 2002.

BOYOKO, Alexis. Le financement basé sur la performance. Text/HTML. Disponível em: <http://www. banquemondiale.org/fr/news/feature/2017/01/19/performance-based-financing-a-win-win-for-health-carepersonnel-and-patients-alike>. Acesso em: 27 nov. 2018.

COLLECTIF, Fondation nationale des sciences politiques Centre d'études et de recherches internationales; HIBOU, Béatrice. La privatisation des Etats. Paris: Karthala, 1999.

CONSORTIUM AEDES/IRESCO. Performance based financing implementation procedures manual, North-West region of Cameroon. Disponível em: <http://www.fbrcameroun.org/cside/contents/docs/Procedure_Manual. pdf>. Acesso em: 6 ago. 2018.

CORDAID AND IADH. Manuel des procédures pour la mise en ceuvre de l'expérience pilote de financement base sur la performance au niveau communautaire dans la province de makamba. Disponível em: $<$ http://www.fbpsanteburundi.bi/ cside/contents/docs/Manuel_FBP_Version_Final_2014.pdf>.

DE WALQUE, Damien et al. Looking into the Performance-Based Financing Black Box: Evidence from an Impact Evaluation in the Health Sector in Cameroon. The World Bank, Policy Research Working Papers. n. 8162, 10 ago. 2017. Disponível em: <http://elibrary.worldbank.org/doi/book/10.1596/1813-9450-8162>. Acesso em: 6 ago. 2018.

DOMIN,J. P. La démocratie sanitaire participe-t-elle à la construction d'un consommateur de soins ? JOURNAL D'ECONOMIE MEDICALE, v. 24, n. 7-8, p. 427-438, 122006.

DOMINIQUE, DARBON. La politique des modèles en Afrique - Simulation, dépolitisation et appropriation. Paris: Pessac: Karthala, 2009.

FAWCETT, Paul et al. Anti-Politics, Depoliticization, and Governance. Oxford, United Kingdom: OUP Oxford, 2017.

FOUCAULT, Michel. Dits et Ecrits, tome 2. Paris: Gallimard, 2001.

FOX, Frederick V.; STAW, Barry M. The Trapped Administrator: Effects of Job Insecurity and Policy Resistance Upon Commitment to a Course of Action. Administrative Science Quarterly, v. 24, n. 3, p. 449-471, 1979.

FRITSCHE, Gyorgy Bela; SOETERS, Robert; MEESSEN, Bruno. Performance-based financing toolkit, $\mathrm{n}^{\circ} 85412$. [S.1.]: The World Bank, 11 ago. 2014. Disponível em: <http://documents.banquemondiale.org/curated/ fr/340251468320950479/Performance-based-financing-toolkit>. Acesso em: 27 nov. 2018.

HAUBERT, Maxime; REY, Pierre-Philippe (Org.). Les sociétés civiles face au marché. Paris, France: Éd. Karthala, 2000. 
IRELAND, Megan; PAUL, Elisabeth; DUJARDIN, Bruno. Can performance-based financing be used to reform health systems in developing countries? Bulletin of the World Health Organization, v. 89, n. 9, p. 695-698, 1 set. 2011.

KEROUEDAN, Dominique; DAUBY, Patrick. Questions autour de la démocratie sanitaire en Afrique. Médecine tropicale, v. 64, n. 6, p. 609-612, 2004.

LAINE, Mathieu. Post politique. Paris: Jean-Claude Lattès, 2009.

LASCOUMES, Pierre; LE GALÈS, Patrick. Gouverner par les instruments. [S.1.]: Presses de Sciences po, 2004.

LETOURMY, Alain; NAIDITCH, Michel. L'émergence de la démocratie sanitaire en France. Santé, Société et Solidarité, v. 8, n. 2, p. 15-22, 2009.

LINDSAY, Morgan. Let's Get Together: Community of Practice for Results-Based Financing is Launched. The World Bank, jul. 2010. Disponível em: <https://www.rbfhealth.org/resource/let\%E2\%80\%99s-get-togethercommunity-practice-results-based-financing-launched $>$. Acesso em: 6 ago. 2018.

MARCUSSEN, Henrik Secher. Les ONG et la construction de la société civile dans les pays en développement. Hommes et société ed. Paris: KARTHALA Editions, 1998. p. 573-597. Disponível em: <http://horizon.documentation. $\operatorname{ird}$.fr/exl-doc/pleins_textes/pleins_textes_7/b_fdi_03_05/010016120.pdf>.

MARITA, Enock et al. Capacity and readiness of civil society organisations to implement community case management of malaria in Kenya. The Pan African Medical Journal, v. 25, n. Suppl 2, 26 nov. 2016. Disponível em: <https://www.ncbi.nlm.nih.gov/pmc/articles/PMC5424268/>. Acesso em: 30 out. 2017.

MAUDET, Gwénaëlle. La « démocratie sanitaire " : penser et construire l'usager. Lien social et Politiques, n. 48, p. 95-102, 2002.

MOUFFE, Chantal. Agonistics:Thinking the World Politically. New York, NY:Verso Books, 2013.

MOUTEL, Grégoire. Médecins et patients: l'exercice de la démocratie sanitaire. Paris: Editions L'Harmattan., 2009. (L'éthique en mouvement).

NIMPAGARITSE, Manassé et al. Measuring and Understanding the Effects of a Performance Based Financing Scheme Applied to Nutrition Services in Burundi-a Mixed Method Impact Evaluation Design. International Journal for Equity in Health, v. 15, p. 93, 14 jun. 2016.

OXMAN, Andrew D.; FRETHEIM,Atle. Can Paying for Results Help to Achieve the Millennium Development Goals? A Critical Review of Selected Evaluations of Results-Based Financing. Journal of Evidence-Based Medicine, v. 2, n. 3, p. 184-195, ago. 2009.

PAUL, Elisabeth et al. Performance-Based Financing in Low-Income and Middle-Income Countries: Isn't It Time for a Rethink? BMJ Global Health, v. 3, n. 1, p. e000664, 1 jan. 2018.

PAUL, Elisabeth et al. Performance-Based Financing to Strengthen the Health System in Benin: Challenging the Mainstream Approach. International Journal of Health Policy and Management, v. 0, n. 0, 15 abr. 2017. Disponível em: <http://www.ijhpm.com/article_3352.html>.Acesso em: 24 nov. 2017.

PAUL, Elisabeth; SOSSOUHOUNTO, Nadine; ECLOU, Dieudonné Sèdjro. Local Stakeholders' Perceptions about the Introduction of Performance-Based Financing in Benin: A Case Study in Two Health Districts. International Journal of Health Policy and Management, v. 3, n. 4, p. 207-214, 2014.

RUDASINGWA, Martin; SOETERS, Robert; BASENYA, Olivier. The effect of performance-based financing on maternal healthcare use in Burundi: a two-wave pooled cross-sectional analysis. Global Health Action, v. 10 , n. 1, 15 jun. 2017. Disponível em: <http://www.ncbi.nlm.nih.gov/pmc/articles/PMC5496061/>. Acesso em: 31 ago. 2017.

RUDASINGWA, Martin; SOETERS, Robert; BOSSUYT, Michel. The Effect of Performance-Based Financial Incentives on Improving Health Care Provision in Burundi: A Controlled Cohort Study. Global Journal of Health Science, v. 7, n. 3, p. 15-29, maio 2015. 
RUDASINGWA, Martin; UWIZEYE, Marie Rose. Physicians' and nurses' attitudes towards performance-based financial incentives in Burundi: a qualitative study in the province of Gitega. Global Health Action, v. 10, n. 1, 27 jan. 2017. Disponível em: <http://www.ncbi.nlm.nih.gov/pmc/articles/PMC5328346/>. Acesso em: 31 ago. 2017.

RUSA, Louis et al. Performance-Based Financing for Better Quality of Services in Rwandan Health Centres: 3-Year Experience. Tropical Medicine \& International Health:TM \& IH, v. 14, n. 7, p. 830-837, jul. 2009.

SCHEDLER, Andreas. The End of Politics? Basingstoke, Hampshire: Palgrave Macmillan, 1996.

SHEN, Gordon C. et al. Incentives to Change: Effects of Performance-Based Financing on Health Workers in Zambia. Human Resources for Health, v. 15, n. 1, p. 20, 282017.

SHROFF, Zubin Cyrus et al. Taking Results-Based Financing from Scheme to System. Health Systems \& Reform, v. 3, n. 2, p. 69-73, 3 abr. 2017.

SINA HEALTH. Rapport du 60ème cours PBF de Cotonou. Disponível em: <http://www.sina-health. com/?p=3354\&lang=fr>. Acesso em: 6 ago. 2018.

SMITH, Julia; BUSE, Kent; GORDON, Case. Civil society: the catalyst for ensuring health in the age of sustainable development. Globalization and Health, v. 12, p. 1-6, 16 jul. 2016.

SOETERS, Robert; HABINEZA, Christian; PEERENBOOM, Peter Bob. Performance-Based Financing and Changing the District Health System: Experience from Rwanda. Bulletin of the World Health Organization, v. 84, n. 11, p. 884-889, nov. 2006.

SOETERS, Robert; VROEG, Piet. Why There Is so Much Enthusiasm for Performance-Based Financing, Particularly in Developing Countries. Bulletin of the World Health Organization, v. 89, n. 9, p. 700, 1 set. 2011.

TABUTEAU, Didier. Démocratie sanitaire. Paris: Odile Jacob, 2013.

TREFON, Theodore. Cahiers africains. 01. ed. Paris : Tervuren: Editions L'Harmattan, 2004. (Cahiers africains : Afrika Studies, série 2003).

TURCOTTE-TREMBLAY, Anne-Marie et al. The unintended consequences of community verifications for performance-based financing in Burkina Faso. Social Science \& Medicine, v. 191, p. 226-236, 1 out. 2017.

WHO. Civil Society Report, Commission on Social Determinants of Health. $\mathrm{n}^{\circ}$ First Draft. Geneva:WHO, out. 2007. Disponível em: <http://www.who.int/social_determinants/publications/civilsociety/en/>. 


\section{A difusão do pagamento pelo desempenho nas reformas do sistema de saúde na África Subsaariana e a despolitização da intervenção na saúde}

\section{Resumo}

Desde seu início em Ruanda em 2006, o estudo do financiamento baseado em desempenho (FBD) na África concentrou a atenção da pesquisa em seus efeitos na melhoria do sistema de saúde ou na consecução dos Objetivos de Desenvolvimento do Milênio (ODM) relacionados à saúde. Da mesma forma, os críticos do FBD se concentraram mais na incapacidade do FBD em transformar os indicadores estruturais do sistema de saúde de forma positiva e sustentável. Até agora, a literatura científica não explorou suficientemente as implicações relativas às mutações ideológicas e operacionais que o PBF está operando. Este estudo investiga esses aspectos do PBF na concepção e operacionalização da intervenção em saúde pública. $O$ conceito de despolitização da ação de saúde pública é proposto nesta análise para descrever a capacidade do PBF para redesenvolver uma política de saúde que leve em conta a intervenção política e estatal e a primazia do setor público, em relação ao campo de competição de mercado em que se encontram o Governo patrocinado e atores não estatais.

Palavras-chave: Financiamento baseado em desempenho, África, despolitização, difusão de políticas.

\section{La difusión del pago por desempeño en las reformas del sistema de salud en África subsahariana y la despolitización de la intervención en salud}

\section{Resumen}

Desde su inicio en Ruanda en 2006, el estudio del financiamiento basado en el desempeño (FBD) en África ha centrado la atención de la investigación en sus efectos sobre la mejora del sistema de salud o el logro de los Objetivos de Desarrollo del Milenio (ODM) relacionados con la salud. Del mismo modo, los críticos del FBD se han concentrado más en su incapacidad para transformar los indicadores estructurales del sistema de salud de manera positiva y sostenible. Hasta ahora, la literatura científica no ha explorado suficientemente las implicaciones con respecto a las mutaciones ideológicas y operacionales que está operando el PBF. Este estudio investiga estos aspectos del FBD en la concepción y la operacionalización de la intervención de salud pública. El concepto de despolitización de la acción de salud pública se propone en este análisis para describir la capacidad del FBD para rediseñar la política de salud desde el ámbito de la intervención política y estatal, y de la primacía del sector público al campo de competencia basada en el mercado y actores no estatales.

Palabras clave: Financiamiento basado en el desempeño, África, despolitización, difusión de políticas. 